\title{
Towards a More Effective Resolution of Anti-Dumping and Anti-Subsidy Disputes: Alternative Dispute Resolution and the Need for an International Trade Court
}

\author{
Abdullah M. Mattar ${ }^{1}$ \\ ${ }^{1}$ Brunel Law School, Brunel University London, Uxbridge, Middlesex, England \\ Correspondence: Abdullah M. Mattar, Brunel Law School, Brunel University London, Uxbridge, Middlesex, \\ UB8 3PH, England. Email: Abdullah.Mattar@brunel.ac.uk
}

Received: June 5, 2014 Accepted: June 13, 2014 Online Published: August 25, 2014

doi:10.5539/jpl.v7n3p57 URL: http://dx.doi.org/10.5539/jpl.v7n3p57

\begin{abstract}
This paper examines the effectiveness of dispute resolution pertaining to anti-dumping and anti-subsidy rules, as outlined in the World Trade Organisation agreement. The paper delves into the weaknesses in the current dispute resolution mechanism and addresses the need for amendment. It establishes a need to install a Dispute Resolution Centre under the auspices of the World Trade Organisation, and a World Trade Court to legally resolve the immense and ongoing trade conflicts between interested parties and large international companies.
\end{abstract}

Keywords: anti-dumping, WTO agreement, anti-subsidy law, dispute resolution DSU, dispute resolution centre DRC, international trade court ITC

\section{Introduction}

This paper examines the Understanding of Rules and Procedures Governing the Settlement of Disputes (DSU) ${ }^{1}$ to demonstrate the effectiveness and weaknesses of these procedures in practice. It will also include additional proposals that could be used to resolve legal disputes between parties in cases of anti-dumping and anti-subsidy.

The DSU is described and legislated for in the WTO agreement, ${ }^{2}$ which has many articles relating to the procedures for dispute resolution in cases of international trade conflict between contracting parties or companies: "The WTO has a remarkable system to settle disputes between WTO Members concerning their rights and obligations under the WTO agreement". ${ }^{3}$ There are several options available for resolving legal disputes between parties under the WTO. ${ }^{4}$ Yet, the dispute settlement system has not yet been utilised successfully to resolve conflicts in a straightforward manner, affording advantages to all parties; indeed, Article 3.7 of the DSU mandates that "the aim of the dispute settlement mechanisms is to secure a positive solution to a dispute". 5

It can also be seen that the majority of contracting parties prefer to resolve legal matters relating to the WTO by initiating judicial processes at the national level, as seen in Paper $3 ;^{6}$ resulting in a high number of cases

\footnotetext{
${ }^{1}$ DSU, Dispute Settlement Rules: Understanding on Rules and Procedures Governing the Settlement of Disputes, Marrakesh Agreement Establishing the World Trade Organization, Annex 2, The Legal Texts: The Results of the Uruguay Round of Multilateral Trade Negotiations 354 (1999), 1869 U.N.T.S. 401, 33 I.L.M. 1226 (1994).

${ }^{2}$ WTO Agreement: Marrakesh Agreement Establishing the World Trade Organization, Apr. 15, 1994, The Legal Texts: The Results of the Uruguay Round of Multilateral Trade Negotiations 4 (1999), 1867 U.N.T.S. 154, 33 I.L.M. 1144 (1994).

${ }^{3}$ Bossche, P. V. B. \& Zdouc, W. (2013) The Law and Policy of the World Trade Organization (3 ${ }^{\text {rd }}$ ed.). Cambridge, England: Cambridge University Press, 157.

${ }^{4}$ Bossche, P. V. B. \& Zdouc, W. (2013) The Law and Policy of the World Trade Organization (3 ${ }^{\text {rd }}$ ed.). Cambridge, England: Cambridge University Press, 161-162.

${ }^{5}$ Shany, Y. (2014) Assessing the Effectiveness of International Courts ( $1^{\text {st }}$ ed.). Oxford, England: Oxford University Press, 196. (Footnote Omitted).

${ }^{6}$ Example the cases against Saudi Arabian Petrochemicals Products in India, Turkey and EU. Indian case: 14/5/2009-DGAD, India v Oman, Saudi Arabia and Singapore [2009] www.commerce.nic.in, accessed 1 June 2014. Turkish case: 2008/40 and 2010/11, Turkey v Saudi Arabia, Kuwait and Bulgaria [2008] Turkish Gazette 27092 - 27 569. EU case: 2011/c 49/10, EU v Oman and Saudi Arabia [2011], Official Journal of European Union c 49/16.
} 
between its contracting parties in relation to anti-dumping. ${ }^{7}$ However, the DSU prefers to resolve legal matters between the contracting parties out of court:

...the DSU prefers parties not to go to court, but to settle their dispute amicably out of court. Accordingly, each dispute settlement process must start with consultations (or an attempt to have consultations) between the parties to the dispute. ${ }^{8}$

The chief factors involved in these alternative dispute resolutions will be discussed in this paper. Introducing alternative methods to resolve disputes could have a directly positive effect on all parties, enabling them to resolve legal conflicts involving international trade relations between nations quickly and smoothly.

This paper will address the topics of dispute resolution relative to anti-dumping and anti-subsidy under the WTO agreement, as it is essential to effect dispute resolution is swiftly when legal matters arise between parties. It will consider the weaknesses present in current dispute resolution mechanisms, in order to avoid these weaknesses in future, and support development. The next stage will be to introduce alternative means of dispute resolution, offering a full explanation of all relevant articles and explaining why contracting parties currently avoid using dispute resolution mechanisms. It will also discuss the advantages and disadvantages of employing alternative resolutions and ways of developing legislation in order to utilise these articles more effectively, rather than using traditional judicial approaches to resolve WTO conflicts between parties. Such approaches also offer new ideas for resolving disputes between parties, establishing new centres for dispute resolution under the WTO (DRC) and in International Trade Court (ITC) to gain more control and further reduce incidents leading to disputes.

\section{Anti-dumping and Anti-subsidy Dispute Resolution under the WTO Agreement}

This section addresses the dispute resolution mechanisms under the DSU, ${ }^{9}$ to support the reader's understanding of the mechanisms informing the rules'. This section will be divided in two main sections; the first will provide an overview of dispute settlement mechanisms under the WTO agreement, particularly regarding anti-dumping and anti-subsidy legal matters. The second section will address the weaknesses of these dispute resolution mechanisms.

\subsection{Overview}

This section, addresses the formal processes of Consultation, Panels and the Appellate Body under the DSU. This overview will help to clarify the mechanisms available for resolving disputes, and help introduce the associated weaknesses referenced in the following section.

\subsubsection{Consultation}

Conflicting parties in any legal dispute related to the WTO can resolve legal issues through consultation "The hope is that the parties will resolve their dispute without having to invoke the formal dispute settlement procedures". ${ }^{10}$ It is the responsibility of the disputants to determine which level the consultation requires: "The manner in which the consultation is conducted is up to the disputing parties". ${ }^{11}$ Once the conflicting parties are engaged in consultation the first stage is for each to gain a clearer understanding of the facts "During the consultation both parties try to learn more about the facts and about the legal arguments of the other party". ${ }^{2}$ The conflicting party must reply to the DSU within 10 days of receiving the consultation request, and has must enter the consultation process within 30 days. ${ }^{13}$ Conflicting parties must enter the consultation process acting in

\footnotetext{
7 According to two sources: 1- World Trade Organisation's website, figures for anti-dumping measures, http://www.wto.org/english/tratop_e/adp_e/adp_e.htm, accessed 19 April 2014 and, 2- The Global Anti-dumping Database under the World Bank

$<$ http://econ.worldbank.org/WBSITE/EXTERNAL/EXTDEC/EXTRESEARCH/0,,contentMDK:22574930 pagePK:64214825 piPK:64214 943 theSitePK:469382,00.html> accessed 1 June 2014.

${ }^{8}$ Bossche, P. V. B. \& Zdouc, W. (2013) The Law and Policy of the World Trade Organization (3 ${ }^{\text {rd }}$ ed.). Cambridge, England: Cambridge University Press, 183. (Footnote Omitted).

9 Jackson, J. H. (2006) Sovereignty, the WTO, and Changing Fundamentals of International Law (1st ed.) Cambridge, England: Cambridge University Press, 152.

${ }^{10}$ Jackson, J. H. (2006) Sovereignty, the WTO, and Changing Fundamentals of International Law (1st ed.) Cambridge, England: Cambridge University Press, 152.

${ }^{11}$ Jackson, J. H. (2006) Sovereignty, the WTO, and Changing Fundamentals of International Law (1st ed.) Cambridge, England: Cambridge University Press, 152.

12 Jackson, J. H. (2006) Sovereignty, the WTO, and Changing Fundamentals of International Law (1st ed.) Cambridge, England: Cambridge University Press, 152.

${ }^{13}$ DSU, Dispute Settlement Rules: Understanding on Rules and Procedures Governing the Settlement of Disputes, Marrakesh Agreement Establishing the World Trade Organization, Annex 2, The Legal Texts: The Results of the Uruguay Round of Multilateral Trade Negotiations 354 (1999), 1869 U.N.T.S. 401, 33 I.L.M. 1226 (1994). Article 4.3.
} 
a good faith; ${ }^{14}$ i.e. "The DSU only requires that consultations are to be entered into a good faith...". ${ }^{15}$ However, the consultation must end within sixty days of the request being made; if this requirement is not met, the parties may request a panel to be established to resolve the dispute. ${ }^{16}$ The consultation often fails to reach conciliation within the sixty day time limit, and there is an option to extend the consultation rather than calling for a panel; Jackson notes, "In fact, consultations often go on for more than sixty days". ${ }^{17}$

Typically, consultation does have a positive effect in terms of resolving the disputes between parties; up "until the end of 2011, almost $42 \%$ of the 427 consultation requests were resolved at the consultation stage". ${ }^{18}$ However, these numbers have since reduced "...the role of consultation in settling the disputes has been significantly weakened in recent years". ${ }^{19}$ Moreover, it can be seen that the terms of consultation are not always clear to members: "In fact, what substantive requirements are in terms of consultation is not clear" ${ }^{20}$ In addition, it can be seen that conflicting parties often prefer action under judicial systems, such as panels or the Appellate Body, in order to resolve conflicts.

\subsubsection{Panels}

Under the DSU, instructions for the establishment of panels are set out in several Articles in detail. ${ }^{21}$ All articles afford panels an important role in the termination of disputes between conflicting parties.

In order to establish a panel, the desire to do so must be presented in writing at the relevant Dispute Settlement Body (DSB) meeting. ${ }^{22}$ This written request should include information regarding whether consultations have been held, the scope of the legal issue, and any other relevant details. There is a period of time related to preparation of the terms of reference made by such a panel, unless the parties to the dispute agree otherwise, within 20 days of the panel's establishment. ${ }^{23}$ The panel must be composed of:

well-qualified governmental and/or non-governmental individuals, including persons who have served on or presented a case to a panel, served as a representative of a Member or of a contracting party to GATT 1947 or as a representative to the Council or Committee of any covered agreement or its predecessor agreement, or in the Secretariat, taught or published on international trade law or policy, or served as a senior trade policy official of a Member. ${ }^{24}$

The members of panels must be independent; in particular referring to their opinion and output; and must not be affected by any other factors, such as their citizenship. ${ }^{25}$ However, if there is no agreement between members of

\footnotetext{
${ }^{14}$ DSU, Dispute Settlement Rules: Understanding on Rules and Procedures Governing the Settlement of Disputes, Marrakesh Agreement Establishing the World Trade Organization, Annex 2, The Legal Texts: The Results of the Uruguay Round of Multilateral Trade Negotiations 354 (1999), 1869 U.N.T.S. 401, 33 I.L.M. 1226 (1994). Article 4.3.

15 Jackson, J. H. (2006) Sovereignty, the WTO, and Changing Fundamentals of International Law (1st ed.) Cambridge, England: Cambridge University Press, 152.

${ }^{16}$ DSU, Dispute Settlement Rules: Understanding on Rules and Procedures Governing the Settlement of Disputes, Marrakesh Agreement Establishing the World Trade Organization, Annex 2, The Legal Texts: The Results of the Uruguay Round of Multilateral Trade Negotiations 354 (1999), 1869 U.N.T.S. 401, 33 I.L.M. 1226 (1994). Article 4.7.

17 Jackson, J. H. (2006) Sovereignty, the WTO, and Changing Fundamentals of International Law (1st ed.) Cambridge, England: Cambridge University Press, 153.

${ }_{18}$ Ahn, D. \& Lee, J. \& Park, J. H. (2013) Understanding Non-litigated Disputes in the WTO Dispute Settlement System, Journal of World Trade, 47:5, p. 991. http://ssrn.com/abstract=2270870

19 Ahn, D. \& Lee, J. \& Park, J. H. (2013) Understanding Non-litigated Disputes in the WTO Dispute Settlement System, Journal of World Trade, 47:5, p. 991. http://ssrn.com/abstract=2270870

${ }^{20}$ Ahn, D. \& Lee, J. \& Park, J. H. (2013) Understanding Non-litigated Disputes in the WTO Dispute Settlement System, Journal of World Trade, 47:5, p. 992. http://ssrn.com/abstract $=2270870$

${ }^{21}$ These are Articles 6 to 20 of the DSU. DSU, Dispute Settlement Rules: Understanding on Rules and Procedures Governing the Settlement of Disputes, Marrakesh Agreement Establishing the World Trade Organization, Annex 2, The Legal Texts: The Results of the Uruguay Round of Multilateral Trade Negotiations 354 (1999), 1869 U.N.T.S. 401, 33 I.L.M. 1226 (1994).

${ }^{22}$ DSU, Dispute Settlement Rules: Understanding on Rules and Procedures Governing the Settlement of Disputes, Marrakesh Agreement Establishing the World Trade Organization, Annex 2, The Legal Texts: The Results of the Uruguay Round of Multilateral Trade Negotiations 354 (1999), 1869 U.N.T.S. 401, 33 I.L.M. 1226 (1994). Article 6.2.

${ }^{23}$ DSU, Dispute Settlement Rules: Understanding on Rules and Procedures Governing the Settlement of Disputes, Marrakesh Agreement Establishing the World Trade Organization, Annex 2, The Legal Texts: The Results of the Uruguay Round of Multilateral Trade Negotiations 354 (1999), 1869 U.N.T.S. 401, 33 I.L.M. 1226 (1994). Article 7.1

${ }^{24}$ DSU, Dispute Settlement Rules: Understanding on Rules and Procedures Governing the Settlement of Disputes, Marrakesh Agreement Establishing the World Trade Organization, Annex 2, The Legal Texts: The Results of the Uruguay Round of Multilateral Trade Negotiations 354 (1999), 1869 U.N.T.S. 401, 33 I.L.M. 1226 (1994). Article 8.1.

${ }^{25}$ DSU, Dispute Settlement Rules: Understanding on Rules and Procedures Governing the Settlement of Disputes, Marrakesh Agreement Establishing the World Trade Organization, Annex 2, The Legal Texts: The Results of the Uruguay Round of Multilateral Trade Negotiations 354 (1999), 1869 U.N.T.S. 401, 33 I.L.M. 1226 (1994). Article 8.1.
} 
the panel within 20 days of its establishment, the Director-General, the Chairman of the DSB and the Chairman of related Councils or Committees shall determine the composition of the panel by appointing it applying a selection process. ${ }^{26}$ Regardless of the means of its establishment, the panel should include at least one member from a developing country, if a developing country requests this, in a case where the conflict is between a developing and developed country. ${ }^{27}$

Once established, these panels take on two roles: supervision and legislative. Regarding the supervisory role, this can be clearly illustrated be referring to an anti-dumping cases considered by a panel. In a case between the United States and Japan, there was specific mention of the panel's supervisory role. "[t]he Panel recommended that the Dispute Settlement Body (DSB) request that the United States bring its measures into conformity with the Anti-dumping Agreement". 28

In this case, it was recommended by the panel that the United States change its regulations to make them compatible with the anti-dumping agreement, making the panel's role legislative. The panel's findings and conclusions were:

[t]he Appellate Body recommends that the DSB request the United States to bring its measures found in this Report, and in the Panel Report [...], to be inconsistent with the Anti-Dumping Agreement and the [WTO Agreement], into conformity with its obligations under those Agreements. ${ }^{29}$

In this section, it can be seen that the panel's mechanisms under DSU rules can resolve conflict between parties. However, there are some weak points that will be addressed in this paper after the overview section.

\subsubsection{The Appellate Body}

The Appellate Body is a unique system referred to resolve disputes between parties; "Thus was born another one of the extraordinary and unique features of the WTO DS process, namely the appeal procedure". ${ }^{30}$ It is the highest level to which disputing parties can take a case; it is similar to a supreme court, and considers the issue of law only; i.e. "An appeal shall be limited to issue of law covered in the panel report and legal interpretations developed by the panel". ${ }^{31}$ The Appellate Body differs different from panels and consultations in regard to processes by which its rules have been developed: "The Appellate Body, unlike panels, is explicitly given the authority to develop (in consultation) its own rules, and this can be an important power" ${ }^{32}$ However, third parties are not permitted to join at the Appellate Body level; it is stated, "Only parties to the dispute, not third parties, may appeal a panel...". ${ }^{33}$ However, the Appellate Body is usually composed of seven persons who are engaged to serve in the Appellate Body for a period of four years. ${ }^{34}$

As mentioned in article 17.5 of the DSU, ${ }^{35}$ the Appellate Body is expected to consider legal matters within 60

${ }^{26}$ DSU, Dispute Settlement Rules: Understanding on Rules and Procedures Governing the Settlement of Disputes, Marrakesh Agreement Establishing the World Trade Organization, Annex 2, The Legal Texts: The Results of the Uruguay Round of Multilateral Trade Negotiations 354 (1999), 1869 U.N.T.S. 401, 33 I.L.M. 1226 (1994). Article 8.7.

${ }^{27}$ Article 8.10: 'When a dispute is between a developing country Member and a developed country Member, the panel shall, if the developing country Member so requests, include at least one panellist from a developing country Member.' DSU, Dispute Settlement Rules: Understanding on Rules and Procedures Governing the Settlement of Disputes, Marrakesh Agreement Establishing the World Trade Organization, Annex 2, The Legal Texts: The Results of the Uruguay Round of Multilateral Trade Negotiations 354 (1999), 1869 U.N.T.S. 401, 33 I.L.M. 1226 (1994).

${ }^{28}$ Appellate Body Report, United States - Anti-Dumping Measures on Certain Hot-Rolled Steel Products from Japan, WT/DS184/AB/R, adopted 23 August 2001.

${ }^{29}$ Appellate Body Report, United States - Anti-Dumping Measures on Certain Hot-Rolled Steel Products from Japan, WT/DS184/AB/R, adopted 23 August 2001, Part 241.

30 Jackson, J. H. (2006) Sovereignty, the WTO, and Changing Fundamentals of International Law (1st ed.) Cambridge, England: Cambridge University Press, 156.

${ }^{31}$ DSU, Dispute Settlement Rules: Understanding on Rules and Procedures Governing the Settlement of Disputes, Marrakesh Agreement Establishing the World Trade Organization, Annex 2, The Legal Texts: The Results of the Uruguay Round of Multilateral Trade Negotiations 354 (1999), 1869 U.N.T.S. 401, 33 I.L.M. 1226 (1994). Article 17.6.

32 Jackson, J. H. (2006) Sovereignty, the WTO, and Changing Fundamentals of International Law (1st ed.) Cambridge, England: Cambridge University Press, 157.

${ }_{33}$ DSU, Dispute Settlement Rules: Understanding on Rules and Procedures Governing the Settlement of Disputes, Marrakesh Agreement Establishing the World Trade Organization, Annex 2, The Legal Texts: The Results of the Uruguay Round of Multilateral Trade Negotiations 354 (1999), 1869 U.N.T.S. 401, 33 I.L.M. 1226 (1994). Article 17.4.

${ }^{34}$ DSU, Dispute Settlement Rules: Understanding on Rules and Procedures Governing the Settlement of Disputes, Marrakesh Agreement Establishing the World Trade Organization, Annex 2, The Legal Texts: The Results of the Uruguay Round of Multilateral Trade Negotiations 354 (1999), 1869 U.N.T.S. 401, 33 I.L.M. 1226 (1994). Article 17.1 and 17.2 .

${ }^{35}$ DSU, Dispute Settlement Rules: Understanding on Rules and Procedures Governing the Settlement of Disputes, Marrakesh Agreement Establishing the World Trade Organization, Annex 2, The Legal Texts: The Results of the Uruguay Round of Multilateral Trade Negotiations 354 (1999), 1869 U.N.T.S. 401, 33 I.L.M. 1226 (1994). 
days: "the appeal process is designed to be very speedy, so the normal timetable calls for a final report within sixty days of the appeal; although, this is sometimes extended to ninety days or more. This imposes enormous pressure on the Appellate Body members, so very heavy work weeks (including working in the evenings and at weekends) are not unknown". ${ }^{36}$

\subsection{Weaknesses within the DSU}

This section considers the weaknesses in the DSU, which require more consideration from contracting parties. There are many points to be disused in this section; for example, the absence of an ability to resolve disputes using alternative measures, the failure to assist developing countries, transparency, the political effect and errors in drafting. However, primary attention will be directed toward consideration of the rights of the private sector concerning the dispute settlement.

\section{- The failure to resolve disputes using alternative measures}

It can be seen that there is no serious movement in regard to resolving the disputes between contracting parties under the WTO using alternative approaches, such as negotiations, mediations or arbitration. Thus, consultation is not progressing in a direction that will reduce the high number of cases between conflicting parties: "In fact, consultation is supposed to serve conflicting roles: bilateral settlement oriented process on the one hand and a mandatory pre-litigation procedure on the other hand". ${ }^{37}$ Contracting parties are less likely to resolve legal matters about the WTO in consultation "...the WTO members brings less consultation requests but at the same time they are less likely to settle by consultation". ${ }^{38}$

Such an example offers no means to resolve legal matters in relation to anti-dumping legislation using alternative measures: "The WTO Anti-dumping code does no longer provide for a mandatory conciliation stage, which is also absent under the DSU". ${ }^{39}$ Contracting parties to the WTO agreement must seek to resolve legal concerns under the WTO using alternative means if they are to halt the increase in the number of legal issues between them under the DSU. There should be greater engorgement for conflicting parties under the WTO agreement, to resolve disputes by applying alternative dispute resolution tactics.

\section{- Lack of assistance for developing countries}

Although some articles under the DSU extend support to developing countries, these countries require more attention and assistance from developed countries and the WTO itself. It is unfair for developing countries to attend dispute resolution proceedings without first being given access to full knowledge and understanding of the legal techniques applied under the DSU and the WTO agreement. Many developing countries require more legal assistance on how to resolve disputes under the WTO, and to reduce the number of claims brought against them. At present, "there is no WTO-like centre offering assistance to developing countries despites the increasing number of claims against them". ${ }^{40}$ Were one instituted, a centre might still be unable to offer adequate support to countries with a low understanding of the terms of the WTO agreement. Fairness between developing and developed countries in regard to legal skills and ability to deal with legal matters remains something that must be achieved.

\section{- Transparency}

The level of transparency is not adequate, especially in regard to panels. Panel data is not available to the public; "As at September 2005 all proceedings have been closed to the public, and indeed portions are closed even to WTO members that are not parties". ${ }^{41}$ Transparency is needed to demonstrate to the public that procedures are being conducted properly and legally.

In addition, transparency can prevent corruption of the dispute process, or between conflicting parties. However, transparency should not affect judicial procedures, or breach confidentiality.

\footnotetext{
${ }^{36}$ Jackson, J. H. (2006) Sovereignty, the WTO, and Changing Fundamentals of International Law (1st ed.) Cambridge, England: Cambridge University Press, 157.

${ }^{37}$ Ahn, D. \& Lee, J. \& Park, J. H. (2013) Understanding Non-litigated Disputes in the WTO Dispute Settlement System, Journal of World Trade, 47:5, p. 989. http://ssrn.com/abstract=2270870 (Footnote Omitted).

${ }_{38}$ Ahn, D. \& Lee, J. \& Park, J. H. (2013) Understanding Non-litigated Disputes in the WTO Dispute Settlement System, Journal of World Trade, 47:5, p. 991. http://ssrn.com/abstract=2270870

${ }^{39}$ Bourgeois, F. H. F. (1998) WTO Dispute Settlement in the Field of Anti-dumping Law, Journal of International Economic Law, 1 (2), 259-276. P. 266. DOI: $10.1093 /$ jiel $/ 1.2 .259$

${ }^{40}$ Papa, M. (2013) Emerging Power in International Dispute Settlement: From Legal Capacity Building to a Level Playing Field?, Journal of International Dispute Settlement, 4(1), 83-109. P. 87. DOI: 10.1093/jnlids/ids022

${ }^{41}$ Jackson, J. H. (2006) Sovereignty, the WTO, and Changing Fundamentals of International Law (1st ed.) Cambridge, England: Cambridge University Press, 155.
} 


\section{- $\quad$ The political effect}

There is a political effect on governments proceeding from dispute resolution policies. There is pressure in such cases between countries, whether from Panels or Appellate Body members, and even within the conflicting countries, to resolve legal matters between them:

Any such proposal would reintroduce a fundamental weakness that was present in the GATT DS producers, politicizing the DS process and encouraging diplomatic and their governments to divert their attention away from the reasoned argumentation and process of a juridical procedure towards lobbying and diplomatic bargaining that would lead to the ultimate decision in a particular case. ${ }^{42}$

However, political and diplomatic pressure can have a negative impact on the dispute settlement process. However, it is acceptable to engage in political negotiations between conflicting parties, in order to resolve legal matters without burdening one or other party in a more emphatic way, particularly if that party is a developing country.

There have been some criticisms that the Appellate Body has been overreaching its mandate as set out under the DSU: "Others have criticized the Appellate Body as "overreaching its mandate" and engaging in "judicial activism" outside its competence and transgressing the allocated powers of the diplomatic process". ${ }^{43}$ This occurs when the DSU's aim to resolve disputes between parties, extends beyond that acceptable under regulations. Some legal scholars have mentioned that the GATT is a legal system that is separate from international law, and which can support the notion of differences between international law and international commercial law,

...some advocates supported the view that GATT was a separate regime, and therefore had a totally stand-alone jurisprudence and legal structure. Many others, including this author, opposed that view, and there are relatively numerous examples throughout the history of GATT that would oppose the "separate regime" theory. ${ }^{44}$

There is combining of the rules of international law and political treatment and the international commercial law. Nevertheless, the same style of dolomitic and political pressure is used under the DSU to resolve legal matters between parties, which does not apply at this stage.

The political pressure resulting from International Law is evident when parties seek to agreed or amend rules under the WTO agreement regarding DSU. International Law differs in the treatment of parties when compared to International Commercial Law. Practitioners in the field of dispute settlement need to be careful not to confuse these two types of regulations when resolving disputes between conflicting parties.

\section{- Faults in the drafting of DSU}

Faults are present in the draft of the DSU: "A well- known fault in the drafting of the DSU has been perplexing". ${ }^{45}$ A particular fault in the draft can be seen in Article 21 (5), Article 22 (6) of DSU. ${ }^{46}$ The relationship between these two articles is mutually exclusive, such that they cannot be applied together. ${ }^{47}$ This can lead to a misunderstanding of the DSU, or confusion between the conflicting parties. However, it might negatively affect the dispute resolution that takes place between parties.

\section{- Private sector involvement in dispute settlement}

The Vienna Convention ${ }^{48}$ includes reference to at what level the WTO can be considered to comprise part of International Law. "Consequently, it is still not easy to judge how the customary international law principle of

\footnotetext{
${ }^{42}$ Jackson, J. H. (2006) Sovereignty, the WTO, and Changing Fundamentals of International Law (1st ed.) Cambridge, England: Cambridge University Press, 201.

${ }^{43}$ Jackson, J. H. (2006) Sovereignty, the WTO, and Changing Fundamentals of International Law (1st ed.) Cambridge, England: Cambridge University Press, 200.

${ }^{44}$ Shany, Y. (2014) Assessing the Effectiveness of International Courts, ( $1^{\text {st }}$ ed.) Oxford, England: Oxford University Press, 165.

45 Jackson, J. H. (2006) Sovereignty, the WTO, and Changing Fundamentals of International Law (1st ed.) Cambridge, England: Cambridge University Press, 203.

${ }^{46}$ DSU, Dispute Settlement Rules: Understanding on Rules and Procedures Governing the Settlement of Disputes, Marrakesh Agreement Establishing the World Trade Organization, Annex 2, The Legal Texts: The Results of the Uruguay Round of Multilateral Trade Negotiations 354 (1999), 1869 U.N.T.S. 401, 33 I.L.M. 1226 (1994).

47 Jackson, J. H. (2006) Sovereignty, the WTO, and Changing Fundamentals of International Law (1st ed.) Cambridge, England: Cambridge University Press, 203

48 Vienna Convention on the Law of Treaties, 1155 U.N.T.S. 331, 8 I.L.M. 679.
} 
treaty interpretation related to preparatory work will be utilised in the WTO jurisprudential system". ${ }^{49}$ As the WTO agreement is an agreement made between states, the private sector in general is not implicated in the agreement; "From the very first case, the appellate Body has made it quite clear the WTO is part of the general international legal landscape for world affairs". ${ }^{50}$ Consequently, private sector representatives cannot attend alternative dispute resolution unless they do so as a third party under the auspices of their governments. This idea relates to a principle in public international law, ${ }^{51}$ which positions the WTO as a component in international law.

The limitations on the attendance of private sector representatives at dispute settlement proceedings under the DSU can be seen as one of its weakness; i.e. it requires the involvement of governments to resolve legal issues:

Companies, industry associations or NGOs cannot have recourse to WTO dispute settlement, nor can they join consultations or be a third party or third participant in panel or Appellate proceedings. Yet it would be incorrect to state that companies, industry associations and NGOs are not 'involved' in WTO dispute settlement. ${ }^{52}$

It is seen as a problem that disputes between private sector companies must be handled by governments, as those who are affected are often not well-represented by their governments, who have no interest in the legal matters affecting them. This provision needs to be reformed to allow private sector companies to resolve legal issues related to the WTO agreement under the umbrella of the WTO, without the involvement of government(s).

This governmental involvement in the WTO conflicts at the DSU level can be summarised into two points:

1- It is necessary for the government to become involved in the conflict, because of the types of cases that arise between parties. To make it clearer, the conflict between parties might relate to the implementation of any of the WTO provisions, where the other party to the conflict has suffered as a result of the implementation of the provisions(s) and disagreement exists over the understanding of the WTO agreement, as was the case between the USA and Japan. ${ }^{53}$ In this particular case, the government was involved in the conflict as well as the companies, as they will be the first to be affected by the results of the resolution processes. Another example is that when the government is involved in the case itself problems are introduced, as in the anti-subsidy cases between Saudi Arabia and others. ${ }^{54}$ In anti-subsidy cases, it is the government that is subsidising the industries, and therefore it is by definition involved in the case.

2- Cases are between private sector companies themselves, and so there may be no reason for the government to become involved. In this situation, the private sector can become involved in the DSU autonomously without the involvement of government, unless it is necessarily for the case to proceed.

Anti-dumping cases affecting Saudi Arabia, typically related to Saudi products that have been sold at less than the normal price. Producers of these products are responsible for defending their pricing to the domestic authorities as well as at the DSU level. Therefore, it would be preferable for private sector individuals to have the option to defend their products without involvement from governments, especially when there has been no government involvement in the production, development or exporting of the product.

Those countries, which have signed the WTO agreement, have expressed an interest in communicating trade discussions among themselves: "Although WTO agreement are negotiated and signed by governments, their objection is not only to sustain governments' international cooperation efforts, but also to help "economic operators"- that is, producers, importers, and exporters- to conduct their business". ${ }^{55}$ However, their interest should also be compatible with the interests of the private sector. This is why the WTO agreement is to be

\footnotetext{
49 Jackson, J. H. (2006) Sovereignty, the WTO, and Changing Fundamentals of International Law (1st ed.) Cambridge, England: Cambridge University Press, 166.

${ }^{50}$ The World Trade Organization, The future of the WTO: Addressing Institutional Challenges in the New Millennium, Report by the Consultative Board to the Director-General, Supachai Panitchpakdi 2004, 52.

${ }^{51}$ Under this principle, in the agreement between states, no parties can become involved in a particular case except the states concerned. In this situation and under the WTO, only the state can become involved in any cases related to the WTO provisions.

${ }^{52}$ Bossche, P. V. B. \& Zdouc, W. (2013) The Law and Policy of the World Trade Organization (3 ${ }^{\text {rd }}$ ed.). Cambridge, England: Cambridge University Press, 177.

53 Appellate Body Report, United States - Anti-Dumping Measures on Certain Hot-Rolled Steel Products from Japan, WT/DS184/AB/R, adopted 23 August 2001.

${ }^{54}$ Cases between Saudi Arabia and India, Turkey and EU. Indian case: 14/5/2009-DGAD, India v Oman, Saudi Arabia and Singapore [2009] www.commerce.nic.in, accessed 1 June 2014. Turkish case: 2008/40 and 2010/11, Turkey v Saudi Arabia, Kuwait and Bulgaria [2008] Turkish Gazette 27092 - 27 569. EU case: 2011/c 49/10, EU v Oman and Saudi Arabia [2011], Official Journal of European Union c 49/16.

${ }_{55}$ Shany, Y. (2014) Assessing the Effectiveness of International Courts, (1 $1^{\text {st }}$ ed.) Oxford, England: Oxford University Press, 191. (Footnote Omitted).
} 
applied to the private sector and why there is no need for governments to become involved and participate in the dispute settlement in relation to conflicts between products from the private sector.

As a result of this, contracting parties under the WTO must consider attributing more access to the private sector, allowing them to apply their cases under the DSU directly and without cover from governments. The majority of the private sector companies involved in disputes tend to be major players in a globalised field, and not under the guardianship of their governments. In truth, some of these companies have as much access to wealth as some developing countries, and consequently are well equipped to represent their own interests in legal matters related to DSU.

An additional issue of concern, is that some companies involved in disputes may be largely owned by foreign investors, operating within the state under investigation. In this case the question arises: how would the government represent such investors in a dispute with another country in the DSU? Typically, it is the private sector that is usually affected by the illegal processes of parties to international trade, and not the government. Although the government may be affected in some cases, the private sector companies are those primarily affected, therefore it is reasonable that they should be given the right to self-represent.

At present, they are only granted representation on appeal to their domestic legal system. Because private sector companies operate within member states, they are responsible for conducting their business disputes first within the domestic legal framework and in accordance WTO provisions. Anti-dumping, for example, has a direct effect on the private sector and industries and can therefore affect national economic systems in the long term. However, in such cases, the private sector and industry must apply to achieve a dispute settlement through their governments; even though, "Anti-dumping relates to conduct of parties rather than conduct of countries". ${ }^{56}$ As argued in this section, the contracting parties should adopt an option for the private sector to have access to the DSU to resolve disputes and take advantage of anti-dumping and anti-subsidy rules.

\section{Alternative Dispute Resolution in Cases of Anti-dumping and Anti-subsidy}

This section concerns DSU rules from different angles, in order to identify non-conventional ways to resolve anti-dumping and anti-subsidy cases in particular, and conflicts related to the WTO agreement in general. Resolutions should be afforded more attention from contracting parties, in order to avoid a lengthy legal process being implicated in anti-dumping and anti-subsidy cases. This will reduce the time spent on pursuing cases, and also reduce costs to the disputing parties: "Furthermore, ADR processes are likely to be less expensive than domestic courts and international arbitration ...". ${ }^{57}$ Moreover, dispute resolution steps will help to terminate the conflict between the parties satisfactorily:

Between 1 January 1995 and 31 December 2012, a total of 454 disputes [were] brought to the WTO, $[\ldots .$.$] the parties were able to reach an amicable solution through consultations, or the dispute was$ otherwise resolved without recourse to adjudication... ${ }^{58}$

This statement shows that a greater number of disputes were being brought to panels, having not been resolved elsewhere. Thereby demonstrating how important it is for contracting parties to use alternative means to resolve conflicts between them, to insure disputes can be resolved simply.

However, a question arises here as to the meaning of the term Alternative Dispute Resolution. Use of the word 'alternative', distinguishes proposals from the 'traditional'. Nonetheless, some argue over the accuracy of using the word. Alternative in this section is understood to describe the methods applied when resolving disputes between parties.

The word 'alternative' suggests a deviation from methods of resolving disputes outside the courtroom. Thus, some have suggested that the term 'appropriate dispute resolution' better describes the array of devices available for the resolution of conflict. ${ }^{59}$

Arguably, there may not be much difference in terminology when deciding to use 'alternative' or 'appropriate' to describe dispute resolution between parties. However, the best way to describe this is by using the expression 'different methods of dispute resolution', as these methods can be applied at any time in the process even when

\footnotetext{
${ }^{56}$ Bourgeois, F. H. F. (1998) WTO Dispute Settlement in the Field of Anti-dumping Law, Journal of International Economic Law, 1 (2), 259-276. P. 269. DOI: $10.1093 /$ jiel $/ 1.2 .259$

${ }^{57}$ Collins, D. (2012) Alternative Dispute Resolution for Stakeholders in International Investment law, Journal of International Economic Law 15 (1), 673-700. P. 676. http://dx.doi.org/10.2139/ssrn.1788243

${ }_{58}$ Bossche, P. V. B. \& Zdouc, W. (2013) The Law and Policy of the World Trade Organization ( ${ }^{\text {rd }}$ ed.). Cambridge, England: Cambridge University Press, 157.

${ }_{59}$ Ackerman, R. M. (1997) Introduction: ADR: An appropriate alternative?, Willamette Law Review 33. 498.
} 
parties are engaged in judicial action. Although 'alternative dispute resolution' is a usable option, it might accurately describe this method of dispute resolution.

Alternative dispute resolution is required between contracting parties to develop an ability to address issues like anti-dumping and anti-subsidy. Taking such steps will help to avoid government involvement in such cases "...there has to be a certain level of government involvement in the private action...", 60 and this could potentially reduce the large number of cases between contracting parties. ${ }^{61}$ However, involvement is considerable in each case "Each case will have to be examined on its facts to determine whether the level of government involvement in the actions of private parties is such that these actions can be properly attributed to a Member". ${ }^{62}$ Moreover, it will help to accelerate trade exchange between nations without encountering obstacles, such as legal issues or processes; as such cases have increased considerably since the 1980s, threatening free trade between nations.

Some means of resolution were mentioned in the DSU, whilst others suggested a more logical way of dealing with issues by developing legal methods.

Of these methods, arbitration under Article 25 and good offices, conciliation and mediation under Article 5 have only played a marginal role; in almost all WTO disputes, Members had recourse to consultations, and, if those were unsuccessfully, adjudication. ${ }^{63}$

These methods need to be applied more in regard to anti-dumping and anti-subsidy cases, in order to reduce the large number of disputes effecting these types of cases. Nonetheless, WTO anti-dumping provisions do not compel parties to resolve disputes using alternative actions, such as mediation and arbitration.

However, Article 5 of the $\mathrm{DSU}^{64}$ states that conflicting parties can undertake the procedures of good office, conciliation and mediation voluntarily. On this point, it can be seen that the agreement itself has given conflicting parties the option either to pursue alternative options, or abide by the judicial process. Moreover, these articles do not encourage contracting parties to resolve and terminate conflicts by using alternative methods, but instead compel conflicting parties to embark on a period of mediation or conciliation. In reference to this point, it can be seen that contracting parties have not prioritised alternative approaches, but instead have preferred traditional methods for ending conflicts under the DSU.

The positive significant effect of alternative methods of dispute resolution mentioned by the DSU (i.e. good offices, conciliation, mediation and arbitration) should be analysed here. Encouraging contracting parties to resolve any legal issues by promoting alternative dispute resolution in the agreement itself as a way of starting the process of anti-dumping and anti-subsidy will help in a number of different ways:

1- It will lower the cost of continuing a claim between the conflicting parties: the cost to the government sector; the need to prepare qualified people (i.e. lawyers and economists) to follow up on cases and undertake investigations, interviews, and other elements of the process. Beginning with a negotiation could help reduce the cost cases, which cause expense to all parties.

2- It will save time for anyone dealing with cases when they go through the judicial process, and will allow them to focus on the most serious a cases. Moreover, the time required for processing issues will be shortened if they can be resolved without recourse to litigation.

\footnotetext{
${ }^{60}$ Bossche, P. V. B. \& Zdouc, W. (2013) The Law and Policy of the World Trade Organization (3 ${ }^{\text {rd }}$ ed.). Cambridge, England: Cambridge University Press, 164.

${ }^{61}$ There is an increasing in the conflicts related to the anti-dumping, which is growing rapidly and requires more attention in order for the number of these cases to be reduced. See these two sources: 1- World Trade Organisation's website, figures for anti-dumping measures, http://www.wto.org/english/tratop_e/adp_e/adp_e.htm , accessed 1 June 2014 and, 2- The Global Anti-dumping Database under the World Bank

<http://econ.worldbank.org/WBSITE/EXTERNAL/EXTDEC/EXTRESEARCH/0,,contentMDK:22574930 pagePK:64214825 piPK:64214 943 theSitePK:469382,00.html> accessed 1 June 2014.

62 Bossche, P. V. B. \& Zdouc, W. (2013) The Law and Policy of the World Trade Organization (3 ${ }^{\text {rd }}$ ed.). Cambridge, England: Cambridge University Press, 164.

${ }^{63}$ Bossche, P. V. B. \& Zdouc, W. (2013) The Law and Policy of the World Trade Organization (3 ${ }^{\text {rd }}$ ed.). Cambridge, England: Cambridge University Press, 306.

${ }^{64}$ This article of the dispute settlement agreement organises these methods to resolve the legal issues between contracting parties. However, it is a brief article, and cannot reflect the importance of these methods. It needs to include more detail if it is to encourage contracting parties to use this method over alternatives. See DSU, Dispute Settlement Rules: Understanding on Rules and Procedures Governing the Settlement of Disputes, Marrakesh Agreement Establishing the World Trade Organization, Annex 2, The Legal Texts: The Results of the Uruguay Round of Multilateral Trade Negotiations 354 (1999), 1869 U.N.T.S. 401, 33 I.L.M. 1226 (1994). Article 5.
} 
3- It will limit the total number of cases, because many would be resolved without recourse to the anti-dumping authorities. Perhaps the process might need to come under the supervision of domestic anti-dumping and anti-subsidy authorities, for alternative approaches to meet WTO agreement standards and avoid illegalities arising. Any decrease in the number of cases would enable authorities to concentrate on other cases and collect information for a database that would be useful to authorities in the future.

4- It would help to avoid a reduction in the quantities of exported products and limits export until completion of negotiations or location of strong evidence of serious damage to either or both the domestic industries concerned. By regulating these processes, it will be easy to acquire a definition of anti-dumping and anti-subsidy techniques and terms in practice, so that such processes become well regulated between the contracting and conflicting parties.

5- It will help to increase the export and exchange of goods between contracting parties in general, without raising new legal issues or barriers, which might otherwise affect the process of exporting.

\subsection{Good Offices, Conciliation and Mediation}

Article 5 of the DSU refers to good offices, conciliation and mediation in relation to the termination of conflict between contracting parties, ${ }^{65}$ whether it is an anti-dumping and anti-subsidy conflict or another international trade related conflict. It is true that good offices, conciliation and mediation differ entirely from negotiation. Negotiation can be considered part of good offices; however, conciliation and mediation are unlike negotiation, because a third party often handles them. Mediation involves a third party in the dispute, in order to resolve the dispute between the parties: "Mediation is the process by which a neutral third party assists dispute parties in reaching a voluntary resolution of their disputes". ${ }^{66}$

Article 5 does not include these approaches to ending conflicts as part of the legal processes involved in disputes under the WTO, in order to avoid any negative impact resulting from the misapplication of regulations. It only mentions the process as it affects this way of ending the conflict, as it is an optional method for conflicting parties to choose: "The DSU also provides for voluntary mediation at any time (an option which is rarely used)..." ${ }^{67}$ Article 5 requires conflicting parties to agree to perform good offices, conciliation and mediation. ${ }^{68}$

The DSU needs to be reformed to encourage conflicting parties to follow procedures set out before embarking on a judicial process. This is similar to most domestic judicial systems, where one party files a case against another, especially in a trade conflict; the court gives the parties time to try to resolve legal issues between them without taking any further action. Encouraging conflicting parties to resolve issues by allowing a period of time to utilise this article in conflicts between parties would therefore help to reduce the number of cases related to WTO provisions (especially anti-dumping and anti-subsidy cases). Conversely, it would also reduce costs and save time for all involved.

However, the most important benefit of alternative methods is the limitation placed on government involvement in international trade cases related to the WTO agreement, as well as a reduction in the number of cases. The cases related to the WTO agreement, especially anti-dumping and anti-subsidy, are increasing in number rapidly, which might hitherto become an obstacle to trade movement and exchange.

\subsection{Arbitration}

Arbitration is one of the possible processes mentioned in Article 25 of the DSU, ${ }^{69}$ as appropriate for assisting in the resolution of a trade dispute between contracting parties in relation to free trade and the movement of products between parties. However, in reality, it is not utilised well in most conflicts, “....and for alternative

\footnotetext{
${ }^{65}$ DSU, Dispute Settlement Rules: Understanding on Rules and Procedures Governing the Settlement of Disputes, Marrakesh Agreement Establishing the World Trade Organization, Annex 2, The Legal Texts: The Results of the Uruguay Round of Multilateral Trade Negotiations 354 (1999), 1869 U.N.T.S. 401, 33 I.L.M. 1226 (1994). Article 5.

${ }^{66}$ Malkawi, B. H. (2013) The feasibility of alternative dispute resolution to resolve intellectual property disputes in Jordan, Journal of Intellectual Property Law and Practice 8(2), 146-153. P.147. (Footnote Omitted). DOI:10.1093/jiplp/jps210

${ }^{67}$ Jackson, J. H. (2006) Sovereignty, the WTO, and Changing Fundamentals of International Law (1st ed.) Cambridge, England: Cambridge University Press, 152. (Footnote Omitted).

${ }^{68}$ DSU, Dispute Settlement Rules: Understanding on Rules and Procedures Governing the Settlement of Disputes, Marrakesh Agreement Establishing the World Trade Organization, Annex 2, The Legal Texts: The Results of the Uruguay Round of Multilateral Trade Negotiations 354 (1999), 1869 U.N.T.S. 401, 33 I.L.M. 1226 (1994). Article 5.

${ }^{69}$ DSU, Dispute Settlement Rules: Understanding on Rules and Procedures Governing the Settlement of Disputes, Marrakesh Agreement Establishing the World Trade Organization, Annex 2, The Legal Texts: The Results of the Uruguay Round of Multilateral Trade Negotiations 354 (1999), 1869 U.N.T.S. 401, 33 I.L.M. 1226 (1994). Article 25.
} 
procedure of arbitration, also rarely used" ${ }^{70}$ Contracting parties generally prefer to apply the judicial process to legal issues relating to the WTO, particularly in anti-dumping and anti-subsidy cases. Using this method to resolve legal issues would, however, hasten the process "Arbitration and other ADR mechanisms tend to provide speedier resolutions of disputes than going through litigation in courts". ${ }^{71}$ Arbitration would also prevent interference by the government. Moreover, it is helpful for reducing the cost of the settlement between parties, as noted by Malkawi, "Arbitration and other ADR mechanisms can significantly reduce the cost of settlement". ${ }^{72}$ However, it more clarification is needed with regard to anti-dumping duty in cases where arbitration decisions permit anti-dumping duty to be applied to any of the disputants.

Article 25 of the DSU emphasises that for arbitration to succeed, the issue itself has to be clear; it should be "clearly defined by both parties", ${ }^{73}$ and understood by both. Moreover, the conflicting parties, who might or might not agree, should determine the standard of clarity. In this paper, the clarity referred to in this article could be more broadly specified, so that it can be applied to all parties, whether they are in arbitration or not. At present, an issue might be clear to one party, but without agreement, arbitration is not possible. Were this definition removed, the article could be broadly applied, thereby eliminating one obstacle to the contracting parties choosing arbitration to resolve conflicts.

Moreover, regarding anti-dumping and anti-subsidy regulations, the government should not intervene in these cases, unless all alternative means of resolving them legally have failed. This will limit state intervention in legal issues, and the process will cost less money and save time.

Article 25 of the DSU mentioned arbitration as one way to resolve the legal issues between contracting parties. However, in general, the implementation of anti-dumping and anti-subsidy measures has not been mentioned as a way to resolve disputes; nor does it encourage contracting parties to use it in conflicts related to them. Therefore, the only way of resolving legal matters, as mentioned in implementations related to anti-dumping and anti-subsidy is by filing legal cases through the judicial process. ${ }^{74}$ This article clarifies arbitration by referring all processes to Articles 21 and $22 .{ }^{75}$ These articles are, however, poorly organised regarding arbitration; especially as regards the matter of applying duties or charges. They deal with arbitration as a government panel and do not mention the results of arbitration or how it will affect the parties involved.

The normal rules of arbitration cannot be applied in the anti-dumping and anti-subsidy conflicts because there is generally no agreement between exporting and importing countries on anti-dumping and anti-subsidy rules. It is only when conflicts arise, that the need to establish agreements emerges. Thus, a slight change in the requirement in Article 25 (i.e. that "[the parties] shall agree on procedures to be followed" ${ }^{\text {"76) }}$ ) is needed in this area. The arbitration here should be recognised as based, not on the agreement between the parties, but on the dispute settlement agreement as a method of resolving these issues.

The assumption of this paper is that arbitration would take place between conflicting parties in relation to anti-dumping and anti-subsidy legal issues; those industries that have been injured or threatened by a dumped imported similar product should first send a letter informing the export company of this issue. The exporting industry should take advantage of the opportunity for negotiation and initiate this immediately. However, a copy of the letter, which is sent to the exporting industry, should also be sent to the exporting and importing countries, as well as the WTO, in order to make them aware of the conflict. After a limited period of time is allowed for negotiation, both parties should enter arbitration, rather than filing a case and involving their governments. The

\footnotetext{
70 Jackson, J. H. (2006) Sovereignty, the WTO, and Changing Fundamentals of International Law (1st ed.) Cambridge, England: Cambridge University Press, 152. (Footnote Omitted).

${ }^{71}$ Malkawi, B. H. (2013) The feasibility of alternative dispute resolution to resolve intellectual property disputes in Jordan, Journal of Intellectual Property Law and Practice 8(2), 146-153. P.148. (Footnote Omitted). DOI:10.1093/jiplp/jps210

${ }^{72}$ Malkawi, B. H. (2013) The feasibility of alternative dispute resolution to resolve intellectual property disputes in Jordan, Journal of Intellectual Property Law and Practice 8(2), 146-153. P.148. (Footnote Omitted). DOI:10.1093/jiplp/jps210

${ }^{73}$ DSU, Dispute Settlement Rules: Understanding on Rules and Procedures Governing the Settlement of Disputes, Marrakesh Agreement Establishing the World Trade Organization, Annex 2, The Legal Texts: The Results of the Uruguay Round of Multilateral Trade Negotiations 354 (1999), 1869 U.N.T.S. 401, 33 I.L.M. 1226 (1994). Article 25.

${ }^{74}$ That can be done by applying an investigation through the governmental anti-dumping sectors at the national level. Moreover, processes under the DSU through consultation, panels and the Dispute Settlement Body.

75 Article 21 refers to the Dispute Settlement Body and the implementation of this DSB, while Article 22 is concerned with compensation in the dispute settlement between parties. Thus, it can be seen clearly that these articles have not addressed sufficient attention to Arbitration as an alternative form of dispute settlement between parties in relation to the WTO.

${ }^{76}$ DSU, Dispute Settlement Rules: Understanding on Rules and Procedures Governing the Settlement of Disputes, Marrakesh Agreement Establishing the World Trade Organization, Annex 2, The Legal Texts: The Results of the Uruguay Round of Multilateral Trade Negotiations 354 (1999), 1869 U.N.T.S. 401, 33 I.L.M. 1226 (1994). Article 25.
} 
arbitration decision should conclude the conflict, and copies of the decision made should be sent to both countries concerned, as well as to the WTO: "Arbitration awards shall be notified to the DSB and the Council or Committee of any relevant agreement where any Member may raise any point relating thereto". ${ }^{77}$ With regard to the duty applied by this arbitration, it should be paid to the domestic industries as compensation not to the governments, as noted in the preceding papers of this thesis.

It is recommended that arbitration decisions should be retained in a database to be accessible to all contracting parties, for use resolving any future legal issues swiftly. Furthermore, this will help to identify any legal issues in the agreement itself and outline the legal process to support changes to faulty legislation to develop them. Arbitration has a proven history in resolving conflicts affecting international commercial relationships; it has been used in this context for some time. The contracting parties to the WTO agreement should reconsider using it as an important means to resolve issues related to this agreement, as it will assist in ending conflict without interference from state parties.

As an example of use of arbitration as a method to resolve legal issues related to anti-dumping law, a case between the United States and the European Community (the EC, now the EU) will be analysed. ${ }^{78}$ The EC initially requested consultations regarding the calculation of dumping margins known as 'zeroing'. After many countries joined this consultation, the EU decided to request the establishment of a panel because there were additional determinations regarding the US obligation under the WTO. ${ }^{79}$ Many non-EU countries joined as third parties and after many communications were circulated among all parties concerned with this issue, the DSB agreed to refer the issues to arbitration, and both parties to the case requested arbitration. Arbitration brought a satisfactory resolution to the matter, and both conflicting parties accepted the decision made under arbitration.

However, there may be cases where one of the conflicting parties chooses not to accept the decision made under arbitration; this then leads to the question of how the issue will then be resolved. The principle of arbitration is that there should be agreement regarding the judgment between conflicting parties, in order for a decision to be accepted and not appealed. However, any decision can also be reviewed by the International Trade Court, the role of which will be discussed later in this paper. This is the Supreme Court overseeing all global international trade judgments.

\section{The role of anti-dumping committees as alternative means of resolving cases}

Under Article 16 of the Implementation of Article VI of the GATT, there is a committee established to deal with legal issues associated with anti-dumping. ${ }^{80}$ A report must be made to this committee outlining any preliminary and final anti-dumping actions, as well as presenting a bi-annual report about anti-dumping actions taken by members. The committee should also be notified of all domestic procedures central to the initiation and investigation of any action.

However, a question arises here regarding whether or not this committee should intervene in illegal processes or actions affecting anti-dumping cases at the domestic level. As mentioned in Article $16,{ }^{81}$ the committee only requires that it be informed of anti-dumping actions or investigations; therefore, it has no power to deal with overflow caused by anti-dumping performed by the domestic authorities. Article 16 does not mention other related functions to this committee.

However, as it has been seen, contracting parties can complain to the committee about any anti-dumping action that they consider being illegal. The committee should play a major role at the international level in relation to anti-dumping to prevent an increase in such cases, as they could become an obstacle to the free movement of international goods between nations. When cases arise, the contracting parties should submit a copy of each initial anti-dumping case or related decisions to the committee, to enable it to play a more active role, by checking on whether every individual anti-dumping initiation or decision and process and implementation of anti-dumping regulations is compatible with the anti-dumping agreement or not. This process would help to

\footnotetext{
${ }^{77}$ DSU, Dispute Settlement Rules: Understanding on Rules and Procedures Governing the Settlement of Disputes, Marrakesh Agreement Establishing the World Trade Organization, Annex 2, The Legal Texts: The Results of the Uruguay Round of Multilateral Trade Negotiations 354 (1999), 1869 U.N.T.S. 401, 33 I.L.M. 1226 (1994). Article 25.

78 Appellate Body Report, United States - Laws, Regulations and Methodology for Calculating Dumping Margins ("Zeroing"), WT/DS294/AB/R, adopted 9 May 2006.

79 Appellate Body Report, United States - Laws, Regulations and Methodology for Calculating Dumping Margins ("Zeroing"), WT/DS294/AB/R, adopted 9 May 2006.

${ }^{80}$ Agreement on Implementation of Article VI of the General Agreement on Tariffs and Trade 1994 (Anti-Dumping Agreement), 1868 U.N.T.S., 201. Article 16.

${ }^{81}$ Agreement on Implementation of Article VI of the General Agreement on Tariffs and Trade 1994 (Anti-Dumping Agreement), 1868 U.N.T.S., 201. Article 16.
} 
reduce the numbers of this type of case and lead to amendment of the necessary articles through recommendations for a legal change.

\subsection{The Role of More Paper into the DSU}

Paper can be an effective way to develop new ideas and approaches in any field; this is especially true in connection with laws and regulations. Governments normally use the best researches from universities and centres (relevant to certain topics) to guide them in making necessary reforms. These researches typically examine laws or regulations theoretically and analyse all the ideas related to them.

However, contracting parties should be encouraged to direct more attention toward paper related to anti-dumping and anti-subsidy measures, in order to develop former policies, to better address price discrimination. The first anti-dumping regulation was established in 1904 in Canada; ${ }^{82}$ it was further developed to become part of the WTO agreement. ${ }^{83}$ However, this regulation requires reform to deal with the relevant issues effectively, as noted in the previous papers.

Paper typically requires considerable time to prove new ideas or develop them. However, it is not an easy process to conduct reform of the WTO agreement, as it differs from other international agreements in relation to the number of WTO members, making it the largest and most complicated international organisation.

A great deal of paper has been conducted regarding the WTO agreement in general and anti-dumping and anti-subsidy in particular. However, changes from the roots upwards have not yet been successfully achieved that reflect the modern concept of free trade between contracting parties. One of the most important ideas thus far, has been to establish a paper centre to deal with anti-dumping and anti-subsidy issues more actively; in particular, producing additional regulations, so that positive changes can result from cases brought. The body of paper relating to the WTO, and anti-dumping and anti-subsidy in particular, require greater consideration by the WTO and contracting parties, including extending values to assist them in developing to the agreement.

\section{The Need for a Dispute Resolution Centre (DRC)}

The WTO should create a centre for dispute resolution to act as a channel for all disputes related to international trade around the world under the WTO. There are many reasons for establishing a centre as follows:

1- To minimise the high number of disputes related to the WTO agreement, particularly anti-dumping and anti-subsidy disputes.

2- To understand the practical application of the WTO and the difficulties arising from the WTO agreement; this will help the contracting parties to make the required changes to the WTO agreement.

3- To reduce the time needed to resolve disputes between parties.

4- To reduce the interference by the government in disputes.

5- To be run by the WTO to insure complete neutrality when settling disputes.

6- To reduce the cost of the dispute resolution between parties; it will be paid for by fees paid by disputants and so be financially independent.

7- To run the entire dispute process in line with the WTO agreement, even in cases of alternative dispute resolutions, so that the parties do not have to deal with different departments or panels to resolve legal issues.

The centre would offer considerable benefit to contracting parties in general and conflicting parties in particular. All disputes under the WTO would be sent immediately to the centre and it would then seek a way to resolve disputes, using the methods mentioned in the previous sections, such as arbitration, mediation etc. The centre may also work on cases, creating committees to oversee each kind of dispute. These Committees would be focused more on strategies related to the WTO, such as trying to reduce the number of conflicts and the WTO mechanism. However, as mentioned above regarding the AD committee, such committees can become involved with this centre to resolve legal issues between; that role can be undertaken before or after the involvement of such a centre in a conflict. This would help to resolve issues more smoothly and at a lower financial cost to parties.

The centre would have other benefits too; for instance, insuring government involvement in international trade

\footnotetext{
${ }^{82}$ Trebilcock, M. J. \& Howse, R. (2005) The Regulation of International Trade, (3rd ed.). Routledge, New York, NY 10016. P. 232.

${ }^{83}$ Agreement on Implementation of Article VI of the General Agreement on Tariffs and Trade 1994 (Anti-Dumping Agreement), 1868 U.N.T.S. 201.
} 
cases is limited. Moreover, the centre would bring in some modest revenue for the WTO, as the conflicting parties would be required to pay fees directly to the centre. This would support engagement in more activities related to international trade in general.

Another positive point when establishing a centre of this kind is to resolve the legal issues related to international trade between those parties who are not members of the WTO, and who are in the process of becoming members under this agreement. Such a centre would, on the one hand, help parties to reform their domestic regulations in order for these to conform to the WTO, and on the other, give them a clearer breadth of understanding of the WTO and its dispute settlement procedures. Moreover, such a centre would be able to establish a section for resolving disputes between parties who are not members of the WTO and who have not applied for membership. However, there would be no legal obligation placed on these parties to attend the centre, although if they agree to resolve their dispute through it, this would mean they accept the WTO dispute settlement mechanism as the method for attaining a resolution. This could facilitate international trade, even for parties who are not members, by making agreements align more closely with WTO principles, so that the mechanisms required for the globalisation of trade between states can be improved.

There are already similar centres, which have been established and function well worldwide to resolve disputes between parties. For instance, the International Court of Arbitration and the International Chamber of Commerce (ICC), ${ }^{84}$ as well as the London Court of International Arbitration (LCIA) ${ }^{85}$ There is also the International Centre for Settlement of Investment Disputes (ICSID). ${ }^{86}$ These centres all serve to resolve the disputes between parties, and the WTO could establish a similar centre to handle disputes related specifically to the WTO and international trade.

At present a centre exists to assist in dispute settlement between members. This centre is the Advisory Centre on WTO Law (ACWL); it is an independent organisation of the WTO, ${ }^{87}$ which provides some services to developing countries in order to understand how they can resolve disputes brought under the WTO. This centre could be merged with the proposed centre and work within it. The suggested centre would then provide a complete service, resolving disputes between parties, and also advising disputants on procedures, or means to resolve disputes, by applying WTO guidelines.

However, the contracting parties may not believe there is a need for such a centre, as there are other methods for resolving legal matters. However, it is argued here that the centre would assist in the smoother resolution of legal matters between parties. It could provide valuable support to all parties, thereby shortening conflict durations and reducing costs. Were the proposal for such a centre adopted, it would be a place for resolving all WTO-related conflicts between parties, offer information on how legal issues can be resolved, and develop up to date WTO articles to meet the needs of contemporary trade. Thus, it is a valid and reasonable proposal, with many attendant advantages, for contracting parties to consider.

\section{The need for an International Trade Court (ITC)}

An International Trade Court (ITC) would be another beneficial innovation, based on the paper findings reported in this thesis. This court would be under the control of the WTO. It would both help to terminate international trade conflicts, and supervise all international legal trade issues worldwide (overseeing national trade courts); therefore, functioning as the Supreme Court for trade.

\subsection{Reasons for Establishing This Court}

The establishment of an International Trade Court must be based on logical reasons and a strong argument. It would not be an easy step to take as there may be many disagreements regarding its efficacy and the necessity for it. Reasons for establishing such an International Trade Court are given in the following sub-sections:

\subsubsection{Protecting Enterprise and the World Economy}

The idea of establishing this court is clearly based on major international trade issues between international companies that have an international effect on the international economic markets. International trade cases brought by such companies involve complicated legal issues, and action can cost billions of dollars, requiring

\footnotetext{
${ }^{84}$ This centre for resolving disputes between conflicting parties in relation to international trade, and was established under the International Chamber of Commerce. For more information, see the official website <www.iccwbo.org $>$ accessed 1 June 2014.

${ }^{85}$ This is a centre for resolving disputes between conflicting parties in relation to international trade, and was established under the International Chamber of Commerce. For more information, see the official website <www.iccwbo.org > accessed 1 June 2014.

${ }^{86}$ This centre has around 158 members, who benefit from it, in relation to resolving international investment disputes. It was established under the World Bank. For more information, see the official website $<$ https://icsid.worldbank.org/> accessed 1 June 2014.

${ }^{87}$ The official website of the Advisory Centre on WTO Law $<$ http://www.acwl.ch/e/index.html $>$ accessed 1 June 2014.
} 
speedy and independent resolution and have to be resolved very quickly. At present, companies typically resolve their legal differences by resorting to the domestic judicial system of one of the parties.

Many international companies have investments and assets worth billions of dollars, and are engaged in trade with other public or government sectors involving similar sums. Thus, the court's judgment has to be very careful and clear when dealing with cases related to such companies. This care relates to the effect of judgments against companies, as such judgment can immediately affect them, the countries where those companies have their head offices, and potentially also the international market.

\subsubsection{The International Trade Court Will Be Stronger Than the Appellate Body}

The Appellate Body is run under the auspices of politicians and diplomats, as shown in this paper. The procedures undertaken by the Appellate Body blend International Law and International Trade Law, thereby making a sound decision that is not necessarily also strong. The International Trade Court, proposed in this paper would make sound judicial decisions without the need for political or diplomatic input from either party. This International Trade Court would therefore by stronger in terms of independence, power, effectiveness and influence over contracting parties.

\subsubsection{Neutrality}

When contracting parties experience conflicts under the WTO agreement, they start typically begin proceedings at the national level. Resorting to the domestic legal systems of conflicting parties does not offer disputants the necessary neutrality, prescribed in International law.

To clarify this, we can consider the case of Apple and Samsung as retailers of smart phones, dealing in billions of dollars. ${ }^{88}$ Apple filed a case against Samsung in the United States regarding certain legal issues related to Intellectual Property code and other legal matters. ${ }^{89}$ As a result, Samsung was required to pay huge damages to Apple and was prohibited from selling Samsung smart phones in the United States for a specified period of time. $^{90}$ This judgment had a direct negative impact on Samsung itself, as well as on competitiveness in the marketplace in the United States. Meanwhile, Apple benefitted greatly, because of the reduced competition.

This was a very complicated case, especially given the reputation of both companies as top manufacturers of smart phones. However, although the judgment affected the companies themselves, the greatest effects were felt by consumers in the United States, as the judgment risked creating a monopoly. Therefore, in such cases, involving complex international trade legal matters and compensation running into billions of dollars a high level of neutrality is essential to proving a legal guarantee to all interested parties. The outcomes of such cases can have a huge effect on the national revenue of countries and the international economic system itself.

Thus far, the allowances made for resolving disputes do not support the principle of neutrality sufficiently, and the issue of which law should be applied to support neutrality could be better addressed by establishing an independent International Trade Court with highly qualified staff focused on managing legal matters affecting international trade.

\subsection{The Relationship between This Court, Enterprises and Contracting Parties}

As mentioned previously, "Individuals, companies, industry associations, labour unions, international organisations and NGOs have no direct access to the WTO dispute settlement system..." ${ }^{91}$ As also discussed above, even if they are the party directly affected, when involved in disputes under the WTO private sector actors must be represented by governments and panels. In this paper's view, it is essential that these companies, who run the economies around the world, should be able to file their cases directly with the WTO without any interference by governments; that is, they should not be seen as a third party.

The International Trade Court would be set up to extend this right to private sector actors, to allow them to apply directly to the court, after exhausting all other methods for resolving legal issues, and without any interference from government. However, as the International Trade Court will be a supreme court (overseeing trade matters related to the WTO), it should also honour the contracting parties (the countries themselves) as part of its

\footnotetext{
88 Annual of the Securities $\quad$ Exchange 2012 $<$ http://www.sec.gov/Archives/edgar/data/320193/000119312512444068/d411355d10k.htm $\geq$ accessed 1 June 2014. For Samsung, see $<$ http://www.samsung.co.kr/samsung/outcome/perfomance.do $>$ accessed 1 June 2014.

${ }^{89} \mathrm{See}<\mathrm{http}$ //www.bbc.co.uk/news/technology-19425051> accessed 1 June 2014.

90 See <http://www.bbc.co.uk/news/technology-19425051> accessed 1 June 2014.

${ }^{91}$ Bossche, P. V. B. \& Zdouc, W. (2013) The Law and Policy of the World Trade Organization (3 ${ }^{\text {rd }}$ ed.). Cambridge, England: Cambridge University Press, 263.
} 
obligation to the WTO responsible for its establishment.

As the contracting parties of the WTO are responsible for insuring their domestic trade legal system is compatible with WTO agreements, there is also a legal obligation form contracting parties to this agreement. Moreover, the legal obligation regarding this International Trade Court will be the same as the WTO obligation, which is ultimately an obligation to the international community to support good international relations between all the states in the world.

\subsection{The relationship between This Court and Appellate Body}

In fact, there is a similar arrangement to this suggested court, under the WTO, and the Appellate Body. Claus-Dieter Ehlermann, who used to work there as a judge, referred to it as the "World Trade Court", ${ }^{92}$ Article 17 of the Dispute Settlement sets out the work of this Appellate Body. ${ }^{93}$

However, it is arguable that this body does not have much effect on resolving conflicts between parties, and so there remains a need to establish an International Trade Court. The Appellate Body considers the cases referred from panels only as stated in Article 17, section 1 "...The Appellate Body shall hear appeals from panel cases..." ${ }^{44}$ This means that no cases can be brought directly by a conflicting party to this Appellate Body for consideration, as cases have to be filtered before going to a higher level, in order to resolve the legal matters between parties. Another point to raise regarding the Appellate Body relates to who can appeal to it.

The only parties who can do so are those stated in Article 17, section 4 "Only parties to the dispute, not third parties, may appeal a panel report...". ${ }^{95}$ Nonetheless, a third party who has an interest in the cases heard by the Appellate Body, may be allowed to submit a written opinion and may be heard by this body: “...Third Parties which [have] notified the DSB of a substantial interest in the matter pursuant to paragraph 2 of Article 10 may make a written submission to, and be given an opportunity to be heard by, the Appellate Body". ${ }^{96}$ If this court could be established, there would be no reason to continue resolving legal matters through the Appellate Body, and its functions could all be transferred immediately to the newly established court. The Appellate Body would merge with the new court, requiring a changing in the DSU and the WTO agreement itself as detailed in the next section.

\subsection{Is There Is Need to Amended the DSU and WTO to Establish This Court?}

The International Trade Court would be run by the WTO agreement, and judges with high qualifications would be selected by the contracting parties to insure the highest standard of dealing with these trade-related legal issues. This could then be used to support a higher level of judgment, which would offer a greater legal guarantee to the conflicting parties. The court would also help to apply many of the WTO articles with greater neutrality than can be guaranteed through other avenues of resolution. As mentioned above, the Appellate Body should be merged with the court, requiring amendment to the WTO agreement and DSU, to establish the court quickly. The new International Trade Court would support the globalisation of trade and be the only option for a final judicial step to resolve trade conflict worldwide.

\section{Conclusion and Recommendations}

Significant effects regarding time, cost and the smooth movement of goods internationally will be the most important elements for encouraging conflicting parties to resolve disputes through alternative resolution. These alternative dispute resolutions include good offices, mediation and arbitration.

Through enacting these resolutions, conflict can easily be terminated via the suggested dispute resolution centre. While dispute resolution has been defined under the WTO agreement, there remains a need to incorporate more inclusive and thorough articles to encourage contracting parties to resolve conflicts efficiently.

\footnotetext{
92 Ehlermann, C. D. (2003) Experiences from the WTO Appellate Body, Texas International Law Journal, 38, p.469.

${ }^{93}$ DSU, Dispute Settlement Rules: Understanding on Rules and Procedures Governing the Settlement of Disputes, Marrakesh Agreement Establishing the World Trade Organization, Annex 2, The Legal Texts: The Results of the Uruguay Round of Multilateral Trade Negotiations 354 (1999), 1869 U.N.T.S. 401, 33 I.L.M. 1226 (1994). Article 17.

${ }^{94}$ DSU, Dispute Settlement Rules: Understanding on Rules and Procedures Governing the Settlement of Disputes, Marrakesh Agreement Establishing the World Trade Organization, Annex 2, The Legal Texts: The Results of the Uruguay Round of Multilateral Trade Negotiations 354 (1999), 1869 U.N.T.S. 401, 33 I.L.M. 1226 (1994). Article 17, section 1.

${ }^{95}$ DSU, Dispute Settlement Rules: Understanding on Rules and Procedures Governing the Settlement of Disputes, Marrakesh Agreement Establishing the World Trade Organization, Annex 2, The Legal Texts: The Results of the Uruguay Round of Multilateral Trade Negotiations 354 (1999), 1869 U.N.T.S. 401, 33 I.L.M. 1226 (1994). Article 17, section 4.

${ }_{96}$ Bossche, P. V. B. \& Zdouc, W. (2013) The Law and Policy of the World Trade Organization ( ${ }^{\text {rd }}$ ed.). Cambridge, England: Cambridge University Press, 157.
} 
The dispute settlement process needs to be reformed, even though it is already working well, as the Consultative Board to the Director-General states,

First, while there are some grounds for criticism and reform of the dispute settlement system, on the whole, there exists much satisfaction with its practices and performance. Second, in appraising ideas for reform or improvement, the most important principle is to 'do no harm'. Caution and experience are needed before any dramatic changes are undertaken. ${ }^{97}$

Nonetheless, these changes to the WTO will require consensus from all the members: "Thus, amendment of the DSU will be needed, and this requires consensus, which can be blocked by any WTO Member", ${ }^{8}$ and this might be not easy to achieve.

However, this paper recommends that it is important to establish a Dispute Resolution Centre (DRC), an International Trade Court (ITC). Through the suggested steps and models, disputes could then be resolved through the Centre as an initial step. The centre would handle a number of different methods for achieving a legal resolution. However, was the centre unsuccessful, the dispute could then be transferred immediately to the International Trade Court (ITC) to make a final decision.

These changes would represent dramatic improvements under the WTO agreement regarding international trade between parties; helping to unify the regulations of international trade, to support globalisation, to unify laws at the domestic and international levels, and to hasten the resolution of disputes in a manner that provides justice to the companies and stakeholders involved.

\section{Copyrights}

Copyright for this article is retained by the author(s), with first publication rights granted to the journal.

This is an open-access article distributed under the terms and conditions of the Creative Commons Attribution license (http://creativecommons.org/licenses/by/3.0/).

${ }^{97}$ Bossche, P. V. B. \& Zdouc, W. (2013) The Law and Policy of the World Trade Organization (3 ${ }^{\text {rd }}$ ed.). Cambridge, England: Cambridge University Press, 49.

${ }_{98}$ Bossche, P. V. B. \& Zdouc, W. (2013) The Law and Policy of the World Trade Organization (3 ${ }^{\text {rd }}$ ed.). Cambridge, England: Cambridge University Press, 58. 